\title{
Problem Solving Learning, Think Pair and Share (TPS) based on Audio Visual Media Improving Oral Activities
}

\author{
Diani Ayu Pratiwi, Nurina Sofiawati \\ Faculty of Teacher Training and Education \\ Universitas Lambung Mangkurat \\ Banjarmasin, Indonesia \\ dianiayupratiwi@gmail.com
}

\begin{abstract}
This study aims to improve Oral Activity by using Problem Solving Learning, TPS learning, Audio Visual Media with Classroom Action Research (CAR), in two cycles of four meetings. The study was conducted at VA of SDN Pemurus Luar 1 Banjarmasin. The data from the observation sheet instrument then analyzed with descriptive technique, then interpreted by using criteria 4 (four) on the indicator of the success of students' oral activity. This study shows an increase in oral activity classically has reached $89.5 \%$ with very good criteria. Problem Solving Learning, TPS, Audio Visual Media can increase students' activity in oral activity.
\end{abstract}

Keywords-Problem Solving Learning, Think Pair and Share (TPS), Audio Visual Media

\section{INTRODUCTION}

The positive impact of globalization is progress in the field of science and technology where the process of education will be increasingly developed with the help of technology because it will affect the more learning references that are easy to access. Along with the development of time from time to time education in Indonesia has always experienced growth, especially in the current era of globalization, education has influenced the development of science and technology. Globalization has had a lot of impact in the field of education, both positive and negative impacts. The positive impact of globalization is progress in the field of science and technology where the process of education will be increasingly developed with the help of technology, because of more and more learning references. Reference learning can support the learning process created in the classroom. The teaching and learning process that is presented will affect the meaning of learning that is accepted by children because learning is related to changes in a child's behavior towards the experiences he repeatedly experiences [1].

Changes in behavior are experienced by children due to the interaction between students and teachers when learning is usually called learning activities. In learning activities, students must play a good role in following the teaching and learning process so that the potential that exists in them can develop to create a conducive learning environment and be able to provide good changes to students, the need for innovative learning design that can improve student learning activities. The importance of the role of the teacher as a facilitator in the learning process will determine the learning process in progress. This is in line with what states that teachers are a determinant of the learning process [2]. Students act as learning subjects that have the greatest strength in the ongoing learning activities, because students have a major role in the ongoing operations of learning, in line with the opinion of Ref [3] stated that students have self-autonomy that they want to be recognized according to their strengths and weaknesses.

Learning activities include the activities of students inside and outside the classroom, one of which is student learning activities is the oral activity. The fact is found in the field based on the results of observations from the data of student learning activities that the implementation of the learning activities process is still conventional; there is no significant learning process innovation. This can be seen from the learning that is still one-way teacher center has an impact on the lack of optimal student learning activities, so students are passive. SDN Pemurus Luar 1 is an institution that strives to improve the quality of education but based on the results of observations on student learning activities in PKN subjects are still passive categories, this is confirmed from data interviews with VA class teachers at SDN Pemurus Luar 1 Banjarmasin.

Students' activities are low in formulating, expressing opinions and discussing which three of them are part of indicators of oral activity students, so that in that aspect according to researchers is important to improve. Information was obtained that in civic subjects the goodness of students in the oral activity was still relatively low. This is evidenced from the observation sheet data on the activities of the kindness of students using an oral activity consisting of aspects of expressing, formulating, asking, giving advice, issuing opinions, holding interviews, discussions, and interruptions, each of which consists of 4 indicators. Civics subjects in 2013/2014 which showed that of 23 students only ten students $(43.5 \%)$ met the Criteria standard, while 13 students $(56.5 \%)$ still had not reached the Criteria for student learning activity indicators on the aspect of the oral activity. Then in 2014/2015 
showed that out of 22 students only 12 students (52.2\%) were declared good in learning and with criteria each aspect achieved good and very good, while 11 students (47.8\%) still not reach the good criteria. Likewise, the latest data in $2015 / 2016$ showed that of the 23 people 14 students $(63.6 \%)$ who met good standards in the teaching and learning process with the criteria of each aspect achieved good and very good, while eight students $(36,4 \%)$ still have not reached the oral activity criteria. Of the three data is one proof that learning still does not lead to the expected innovative learning.

Based on the results of observations made at VA class students of SDN Pemurus Luar 1 Banjarmasin, students still have not been able to participate in learning activities well in learning activities. The active learning of students according to Paul D. Dietrich has indicators that are visual activities, oral activities, listening activities, writing activities, drawing activities, emotional activities, motor activities, and mental activities. In SDN Pemurus Luar 1 Banjarmasin, from the eight indicators, the low ability of students is in the oral activity aspect of students with indicators, namely stating, formulating, asking, giving advice, expressing opinions, conducting interviews, discussions, and interruptions, because conditions in the field indicate that learning takes place it is still conventional or one-way, where students only memorize and memorize the material taught, without an activity that leads to problem-solving skills that can stimulate the development of activities expected in the aspect of the oral activity.

Learning also only uses the lecture method, in the implementation the teacher dominates learning so that students have less opportunity to be directly involved, students are only involved if the teacher gives an opportunity to ask questions, those efforts are only used by certain students, the concept of questions asked by students is only around the thing that students don't understand is not the question of increasing students' curiosity. So that the motivation of students to find out/build knowledge independently is very minimal, and the impact on learning becomes meaningless. During the learning process, students also appear to lack confidence in asking questions and expressing their opinions. Students also only rely on information available in the book and only wait for direction from the teacher in solving problems. Also, the assignments are given only answer questions that are in the book without any other activities that encourage students to both participate in learning activities.

During the learning activities, there have not been seen activities that train interactive learning students to build communication through meaningful discussion so that learning students tend to show their respective egos still. This has an impact on the process of student cooperation, communication and interaction between fellow group members are not well interwoven, and there are no learning activities that encourage students to utilize information and communication technology to increase their insight into learning until the process of expressing and exchanging opinions is not well interwoven. Looking at the conditions that occur in the field, of course, the learning activities process is not conducive and effective. Therefore there needs to be an improvement to improve student learning activities, especially in the oral activity, in this case, the researcher wants to improve in the aspect of expressing, formulating, issuing opinions and discussing.

If this problem continues to be left it will have a negative impact on the quality of learning in the classroom, especially in the VA class of SDN Pemurus Luar 1 Banjarmasin. The learning process will be hampered and the results will be less than optimal and will also have an impact on student learning achievement. Also, it will also have an impact on the personality of students in the future, because the purpose of Civics learning is to shape the personality of students so that they have a state awareness and have attitudes and behaviors that love the country.

Efforts can be made so that the problem does not continue continuously, so by applying a learning method used in innovative learning that is no longer monotonous like the lecture method, but the method used is more flexible and dynamic that adapts to the needs of students. The methods used in innovative learning TPS models in it contain discussion, in this model involving students directly to discuss problems and find alternative solutions to problems. So that with discussion, students will be able to think critically and well in learning [5]. Ref [6] stated that in the learning process, teaching activities are not only determined by the wishes of the teacher, but also by involving students.

To trigger the activities of students in expressing, formulating, issuing opinions, and discussing the need for cooperative learning so that the expected aspects can develop very well. Cooperative learning is a learning model wherein the learning process takes place, students are heterogeneously divided into small groups for collaborative learning and collaboration whose members consist of 4-6 people [7]. With cooperative learning, it is expected that students can conduct discussion activities and other aspects of the oral activity.

Cooperative learning has various types or models of learning, one of them is the learning model of Problem Solving. This study uses the Problem Solving learning model as an effort to solve problems. Problem Solving is "a skill that includes the ability to search for information, analyze situations, and identify problems with the aim of producing alternatives so that decisions can be taken to achieve goals" [5]. In this learning model students are given problems or cases to be solved in groups, with groups of students able to hold intense discussions, the discussion becomes one indicator to improve students' oral activity abilities. This learning model can stimulate students in thinking that starts from looking for data to form conclusions so students can take meaning from learning activities.

Problem Solving learning model is a method that can train students to think creatively in dealing with various problems both personal problems and group problems to solve alone or together. The teacher's task in this method is to provide cases or problems for students to solve [8]. Besides that, researchers are trying to give the best solution by combining Problem Solving learning models with TPS learning models.

In addition to using the Problem Solving learning model, researchers also combined the model with TPS learning models, which this learning model gives students time to think, 
respond and help each other. "Think Pair and Share model cooperative learning is relatively simpler because it does not take a long time to arrange to seat or classify students and this learning trains students to dare to think and appreciate the opinions of friends" [5]. In addition to combining Problem Solving and TPS learning models, researchers also combine with Audio Visual based media. Audio Visual Media is a media that can develop abstract capabilities to be concrete and able to increase student independence. Ref [9] that the use of Audio Visual can increase student learning independence.

The steps in the Audio Visual based Problem Solving and TPS based learning models are as follows; (1) The teacher prepares the subject matter as well as the type of problem or case that will be given to students using Audio visual media (Problem Solving), (2) The teacher delivers the subject matter material to students as an introduction using Audio visual media (Problem Solving), ( 3) The teacher divides students into several work groups as a first step (Problem Solving), (4) The teacher raises questions by giving one type of problem or case to all classes related to subjects (Problem Solving and TPS), (5) Students work the same in each group to solve the issues and cases given by the teacher (Problem Solving), (6) The teacher provides assistance and direction needed so students can solve the problem at hand (Problem Solving) (7) During learning and work solving problems, students allowed to look for other reference sources as a reference as well as to foster motivation for independent learning (Problem Solving), (8) After s students succeed in solving the problems faced, students are asked to make reports and conclusions (Problem Solving), (9) The teacher asks students to pair with their peers to start thinking about the questions given by the teacher at a particular time (TPS) (10) (Share) Students individually represent groups or both go forward together to report the results of their discussions in front of the class to share knowledge with other groups (Problem Solving and TPS).

Therefore, researchers combine learning models, namely Problem Solving learning models, TPS and audio visual media to overcome the learning problems that exist in the VA class Pemurus Luar 1 SDN Banjarmasin. Thus, researchers try to solve these problems through classroom action research with the title: "Learning Problem Solving, TPS Based on Audio Visual Media Increases Oral Activity.

\section{METHOD}

Based on the problems found, namely the lack of student learning activities on oral activity in the VA class SDN Pemurus Luar 1 Banjarmasin, the type of research applied uses Classroom Action Research (CAR) with a qualitative approach that starts from the planning, implementation, observation and reflection stages. This study was conducted in 2 cycles or as many as four meetings. This research was done in VA Class Pemurus Luar 1 SDN Banjarmasin with 22 students consisting of 11 women and 11 men.

Data are analyzed qualitatively, namely oral activity students. Data is generated from the instrument sheet of the observation sheet, then explained with descriptive techniques and illustrated in the form of tables and graphs, then interpreted using criteria on the indicators of the success of student activities in the oral activity, namely expressing, formulating, issuing opinions, and discussion. The indicator of success set at $\geq 80 \%$ of students achieving good criteria is even very good.

Procedure in this study starts from the researcher observing the student activity before taking action as an effort to measure in acting. Then the researcher designed the activity in the first meeting, carried out the action based on the results of the planning carried out after the implementation of the activities carried out the stage of observation and reflection on the activities that have been carried out in the learning process. The observation phase is carried out during the learning process activities taking place using the student activity indicators.

\section{RESULTS AND DISCUSSION}

The research activity was conducted in two cycles in each cycle consisting of two meetings; each meeting carried out planning activities using Problem Solving Learning, AudioBased Media Pair Thinking and Share (TPS), implementation, observation, and reflection. Based on the results of the application in the first cycle of the first meeting, it can be seen that there are still no students who reach the criteria very well and students who reach the good criteria are 13 people $(59.1$ $\%)$. In the fairly good criteria there are seven students with a percentage of $31.8 \%$, and two students who are only in the poor criteria with a percentage of $9.1 \%$. Seeing conditions like this are still far from the indicators of success set $\geq 80 \%$ of students to achieve good criteria and even very good. These results have not reached the expected completeness criteria because most students still have obstacles to play a useful role in the learning process. As with the oral activity aspect, the indicators state clearly and precisely and confidently, it is still difficult for students to put forward because there are many students who have not fully paid attention to the teacher's explanation so that the ability to express is also difficult to develop, thus an effort is needed to focus students on teacher delivery. Similarly, formulating and issuing opinions is also still not able to be understood by students because students are still not familiar with learning Problem Solving, TPS Based on Audio-Visual Media. For discussion, activities have been carried out by students even though still not by the indicators of expected achievement.

At the second meeting, improvements were made based on the results of reflection at the previous session to improve the effectiveness of learning activities so that the expected achievements could be achieved. The results obtained from the data in the second meeting three students were completing very good criteria and 12 students achieving good criteria. So the classical completeness in this second meeting was 15 students with a percentage of $68.2 \%$ who fulfilled good and very good criteria. These results are an increase from the previous results, but there are still five students who only achieve the criteria quite well and two students who still reach poor criteria. Of course, the results need to be increased again at the next meeting. Students who are in very good criteria already have as many as three people $(13.6 \%)$ and students who are in good criteria there are as many as 12 people $(54.6 \%)$. So that the total students who reach the criteria very well and well are 15 people with a percentage of classical completeness of $68.2 \%$. Based on the results of the oral activity observations, the students showed an increase from the previous meeting, 
although it still could not be stated that this study was successful because it had not reached the specified indicators, the increase was due to an increase in scores on each student's oral activity criteria.

At the third meeting the increase in the number of good and very good criteria. A total of 11 students $(50 \%)$ or part of the number of students in the class have been able to reach the criteria very well, and there are six students (27.3\%) achieving good criteria. But there are still five students $(22.7 \%)$ still achieving quite good criteria. So the classical completeness in this third meeting was 17 students with a percentage of $77.3 \%$ who reached the criteria of good and very good. These results are an increase from the previous results. Although the results increased from the previous meeting, but the results need to be increased again at the next meeting.

The researcher then continues to meet again with the stages of planning, implementation, observation, and reflection. From the data at the 4th meeting, it is known that there are 20 students who have achieved good and very good criteria. While the criteria are quite good, there are still two people. This was obtained based on the results of the observation of oral activity which continued to increase from the previous meeting, from the total overall completeness in classical student activities of $89.5 \%$ which had reached the criteria of good and very good. But there are still $10.5 \%$ of students who are on the criteria quite well. Based on these results, the activities of students have reached and meet the success indicators set by the teacher, namely $\geq 80 \%$ of students reach the criteria of good and very good. This result must be maintained.

At the 1st meeting, only $59.1 \%$ of students achieved the criteria of "Good and Very Good." From the results of the 1st meeting, it continued to be improved in every aspect whose implementation was still not carried out to the maximum, so that at meeting two the results increased to $68.2 \%$. The results at meeting 2 increased but still did not meet the indicators of success. From these results, the teacher continues to strive to make improvements so that student learning activities in the aspect of the oral activity can be maximized. Continuing on the meeting three results also increased to $77.3 \%$, but these results still did not reach the specified criteria. At the next meeting, the teacher continued to try to improve performance in the learning process so that the results obtained at meeting four again increased to $89.5 \%$ of students obtained the criteria of "Good and Very Good." The results at meeting four have met and reached the predetermined indicators of success. As for knowing the trend of increasing the oral activity on each criterion can be seen in the following graph:

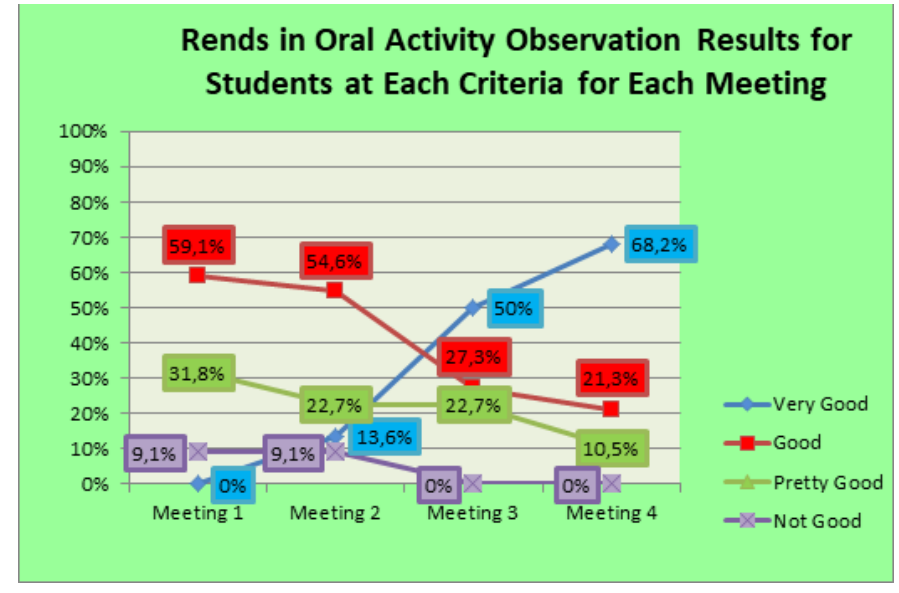

Fig. 1. Graph of Trends in Observation Results of oral activity Each criterion

Based on fig 1, it can be seen that at each meeting the number of students who reached good and very good criteria tended to increase until the final meeting. While the number of students in the criteria is quite good and poor at each meeting tends to decrease.

Based on the results of observations of oral activity at meetings 1 to 4 in learning activities using a combination of Problem Solving learning models, TPS, and Audio visual media can be seen that oral activity students tend to increase at each meeting and successfully reach the predetermined indicator success, namely $\geq 80 \%$ of students reach the criteria of "Good and Very Good". These results can be seen from the following figure:

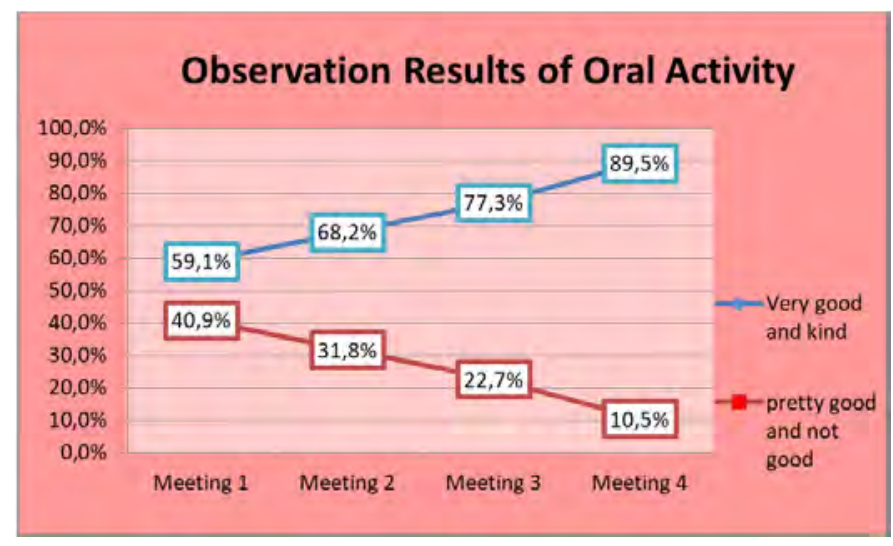

Fig. 2. Graph of Trends in Observation Results of oral activity Every Meeting

Based on the description of the data shows that students' oral activity at each meeting tends to increase. At each meeting, the number of percentages of students' oral activity observations on the criteria of good and very good continued to increase, while the criteria for fairly good and not good tended to decrease. So that the improvement of students' oral activity has met and achieved the predetermined indicators of success.

The increase in oral activity of students was due to the selection of the learning model and strategy carried out by the teacher, which greatly influenced the success of the learning process and made students' activities more than usual. Ref [3] 
stated that "the use of appropriate teaching strategies is very important to note, therefore teaching strategies that are used for the instructional achievement / certain teaching must be able to foster attraction for the learner. Because with high attractiveness when delivering teaching materials causes students to study the field of study with the intensity of interest and high attention ". The high attraction effort is one of them supported by the use of audio visual media. Also, the use of learning strategies carried out by researchers in this study can foster students' interest and attention to the material being taught, while also being able to lure students better during the learning process. Increasing the oral activity of students in the learning process is because the learning model used by the teacher in the learning process can maximize student involvement during the learning activities. Ref [10] stated that "student success in learning also depends on the material presentation model. The material presentation model is fun, not boring, interesting, and easy to understand by students, of course, positively relates to the success of learning".

Through a combination of Problem Solving learning models, TPS, based on audio visual media, during the learning process students not only listen to the explanations of the material delivered by the teacher, but students are also involved in thinking, students are invited to think about problems and find solutions or solutions problem of the problem given. This is by the objectives of the Problem Solving learning model that the teaching and learning process through problem-solving can familiarize students with facing and solving problems skillfully when facing problems in life in the family or society and this method can stimulate the development of students' ability to think comprehensively [11].

In student learning also learning in groups, the goal is that students can work together in completing tasks with other students and can share information between students and help each other if there are other students do not understand the material. Ref [12] state that children enjoy working in groups, from their association with peer groups, children learn important aspects of the socialization process, such as learning to meet group rules, learning loyal friends, learning does not depend on being accepted in the environment, learning to accept responsibility, and learning with others in a healthy manner".

In addition, the success in improving the oral activity of students is also not immune from the efforts of the teacher in creating a teaching atmosphere during the learning process. Ref [10] stated that "the teaching atmosphere is one of the factors that determine the success of students in learning. The calm atmosphere of teaching, the occurrence of critical dialogue between students and teachers, and fostering a good atmosphere among students will certainly give more value to the teaching process. So that students' success in learning can increase optimally ". As it is known that in organizing classes it is necessary to arrange effective classroom settings, equipment arrangements to be used, organize students in groups. Ref [13] which stated that "effectively managed classrooms are classrooms that run smoothly, with very little confusion and retardation, and maximize learning opportunities students. It is impossible for teachers to conduct learning or for students to work productively if they do not have guidance on how they behave, when and how they move around the room, where to sit when they can sit and not interrupt the teacher, and how much acceptable objection".

When carrying out research during a meeting 1 teacher was still very difficult in managing the class. This is because students are not familiar with problem solving learning activities, TPS based on Audio Visual media. Through reflection, the teacher can find out where the difficulties and problems in managing the class are located. By making improvements in subsequent meetings the teacher is able to manage the class well so that activities and learning activities can run effectively.

These oral activity student observations were supported by research conducted by several previous researchers, namely: Ref [14] study using the Problem Solving learning model showed an increase in the quality of student activities to 85.71 $\%$ with very good criteria. The use of TPS learning model is also supported by previous research, namely: the results of Ref [15] research using TPS learning models indicate that there is an increase in the quality of student activities with a percentage of $84.36 \%$ criteria very well. Another researcher in Ref [16] used the TPS learning model also showed that there was an increase in the quality of activities gained $80.69 \%$. Ref [17] also shows that there is an increase in the quality of student activities using the TPS model. Previously, the use of audio visual media has also been done by many previous researchers, ref [9] with the title of research assisted by audio visual media capable of improving student learning outcomes and independence.

\section{CONCLUSION}

Conclusions on the results of the research conducted at the VA class at SDN Pemurus Luar 1 Banjarmasin on the subject of Civics Education in the Joint Decree can be concluded that the activities of the oral activity students on aspects stated, formulated, issued opinions, and discussion had reached indicators of success at the final meeting, namely $89.5 \%$ with very good criteria when using Problem Solving, TPS Learning, based on Audio-Visual Media.

Based on the results of the research, discussion, and conclusions described earlier, some suggestions can be stated as follows: (1) Teachers should be able to use the results of this study as a reference in using innovative and varied learning models to improve the quality of student learning, so that it can trigger students' enthusiasm for learning motivation and can improve oral activity of students, (1) Principals should be able to help teachers improve the quality of student learning by providing guidance and guidance in implementing innovative and varied learning strategies and models in carrying out learning activities in order to improve the quality of learning at the elementary school level. (3) For Other Researchers, the results of this study can be used in such a way and become one of the reference materials to help write scientific papers.

\section{REFERENCES}

[1] A. Susanto, Theory of Learning and Learning in Elementary School, Jakarta: Kencana Prenada Media Group, 2013.

[2] D. J. Priansa and A. Seyiani, Student Management and Learning Models: Smart, Creative and Innovative, Bandung: Alfabeta, 2015. 
[3] A. Suriansyah, et al, Learning strategies, Jakarta: PT Raja Grafindo Persada, 2014.

[4] O. Hamalik, Manajemen Pengembangan Kurikulum, Bandung: PT Remaja Rosdakarya, 2007

[5] A. Shoimin, 68 Innovative Learning Models in the 2013 Curriculum, Yogyakarta: AR RUZZ MEDIA, 2014.

[6] W. Sanjaya, Learning Strategies Oriented to Educational Process Standards, Jakarta: Kencana, 2013.

[7] A. Setiani and D. J. Priansa, Manajemen Peserta Didik dan Model Pembelajaran: Cerdas, Kreatif, dan inovatif, Bandung: Alfabeta, 2015

[8] R. A. Sani, Learning Innovation, Jakarta: PT Bumi Aksara, 2013.

[9] D. A. Pratiwi, "Cooperative Learning Group Investigation Assisted by Audio Visual Media to Improve Learning and Independence Results," Thesis, Basic Education Study Program, Postgraduate, State University of Malang, 2017.

[10] A. Susanto, Theory of Learning and Learning in Elementary School, Jakarta: Kencana Prenada Media Group, 2015.

[11] N. Suryani, and L. Agung, Teaching and Learning Strategies, Yogyakarta: Ombak, 2012.

[12] M. S. Sumantri, Theory and Practice Learning Strategies at the Basic Education Level, Jakarta: Rajawali Pers, 2015.

[13] N. Mingus, Class Management for Elementary School Teachers, Translation by Arif Rahman, Jakarta: Kencana, 2015.

[14] A. Wibowo, Improving PKn Learning Results Decision Material Together Through Learning Model Problem Valuing Class V SDN Sungai Besar 9 Banjarbaru, Banjarmasin: PGSD FKIP University of Lambung Mangkuurat, 2014.

[15] Z. Helmi, Improving Civics Learning Outcomes in Decision Concepts Together with Melalui Learning Models Combination of Group Investigation (GI), Numbered Heads Together (NHT), and Think Pair and Share (TPS) in Class V Students of SDN Kebun Bunga 9 Banjarmasin, Banjarmasin: PGSD FKIP University of Lambung Mangurat, 2016.

[16] R. Yuliati, Improve PKn Learning Outcomes About Central Government Systems Through Cooperative Learning Models Think Pair and Share (TPS) Type IV SDN Handil Bakti Barito Kuala, Banjarmasin: PGSD FKIP University of Lambung Mangkuurat, 2014.

[17] K. Pahlipi, Improving PKn Learning Outcomes Organizational Materials Using Think Pair and Share (TPS) and Word Square Type Models in Class V Students of Kelayan Elementary School in 5 Banjarmasin, Banjarmasin: PGSD FKIP University of Lambung Mangkuurat, 2015. 